\title{
Does foraminiferal test size reflect changes in palaeoenvironmental conditions?-a case study from the southern Svalbard shelf
}

\author{
Maciej M. Telesiński (D, Natalia Szymańska (D), Joanna Pawłowska (D) \& Marek Zajączkowski (D) \\ Institute of Oceanology, Polish Academy of Sciences, Sopot, Poland
}

\begin{abstract}
Although the environmental factors influencing the growth rate and reproduction of benthic foraminifera are known, the relationship between foraminifera test size and environmental variables remains unclear, especially on geological timescales. In this article, we present two records of benthic foraminiferal test size over the last 14000 years from the southern Svalbard shelf. We use statistical correlation to relate test size changes with environmental conditions recorded by other proxies, including benthic $\delta^{18} \mathrm{O}$ and $\delta^{13} \mathrm{C}$, foraminiferal flux and abundance, and relative abundances of different ecologically indicative foraminiferal groups. The general trends in test size were relatively consistent between the two cores. Still, we found that none of the analysed proxies was statistically correlated with the test size in both records. This leads to a conclusion that foraminifera size is primarily impacted by local oceanographic conditions. These local conditions are partly influenced by global oceanographic transitions. Therefore, large-scale changes can have a secondary impact on foraminiferal test size. The analysis of test size correlation between species similarly revealed that not all species react consistently to environmental changes. Our results indicate that foraminiferal test size cannot be used as a universal and straightforward proxy, but in combination with other methods it can yield valuable palaeoenvironmental information.
\end{abstract}

\begin{abstract}
Keywords
Foraminifera; deglaciation; Holocene; size; palaeoecology; palaeoenvironment
\end{abstract}

\section{Correspondence}

Maciej M. Telesiński, Institute of Oceanology, Polish Academy of Sciences, Powstańców Warszawy 55, 81-712 Sopot, Poland. E-mail: mtelesinski@iopan.pl

Abbreviations
ArW: Arctic Water
AW: Atlantic Water
BA: Bølling-Allerød
cal. Ky BP: calibrated thousands of years
before the present
ESC: East Spitsbergen Current
L: greatest diameter of a shell
TAW: Transformed Atlantic Water
W: shell width, measured perpendicular to L
WSC: West Spitsbergen Current
YD: Younger Dryas

\section{Introduction}

The growth rate and reproduction of foraminifera are supposed to be governed by the interplay of various environmental factors. Temperature is usually listed as the most important (e.g., Boltovskoy \& Wright 1976; Gross 2000; Nigam et al. 2008), as it controls vital activities of foraminifera. Laboratory culture studies (e.g., Bradshaw 1955; Bandy 1963; Lewis \& Jenkins 1969) showed that colder waters cause cosmopolitan foraminifera species to grow larger. Apparently, a higher temperature leads to quicker reproduction resulting in smaller specimens (Bradshaw 1961; Boltovskoy \& Wright 1976). However, the opposite trend has also been observed (e.g., Theyer 1971). Next to temperature, oxygen concentration has been listed as another important factor in test size and the volume-to-surface ratio of foraminifera (Bernhard 1986; Kaiho 1994;
Keating-Bitonti \& Payne 2016). Other factors controlling foraminiferal growth include food availability (Boltovskoy \& Wright 1976), light intensity (in the case of symbiont-bearing foraminifera), salinity (e.g., Stouff et al. 1999; Nigam et al. 2006) and pH (e.g., Le Cadre et al. 2003; Kuroyanagi et al. 2009).

Knowledge about foraminiferal test size response to specific environmental factors inferred from field studies is scarce and mainly concerns million years timescales (e.g., Bernhard 1986; Kaiho 1998). The majority of studies of foraminifera test size focus on modern assemblages (e.g., Corliss \& Silva 1993; Duchemin et al. 2007; Keating-Bitonti \& Payne 2016, 2018). There is a lack of studies focusing on foraminifera size changes in geological timescales, especially in the North Atlantic, a region that has experienced major oceanographic changes impacting the global climate over the last 14000 years. 
The majority of environmental studies attribute foraminiferal size variability to a combination of factors, as the response to one parameter may also be influenced by another (Murray 2006). Environmental variables that control the test size of foraminifera have changed over the postglacial and the Holocene mainly in accordance with changes in AW/ArW advection to the Svalbard shelf (e.g., Ślubowska-Woldengen et al. 2008; Rasmussen $\delta$ Thomsen 2015). It is well-known that benthic foraminiferal abundance and diversity have varied significantly in this region over the last ca. 14000 years (e.g., Łącka et al. 2015; Telesiński et al. 2018). Clear signals of size response of deep-sea foraminifera to longterm environmental changes were reported on the scale of hundreds of millions of years (Kaiho 1998). However, the response of foraminiferal test size to oceanographic changes in high temporal resolution studies has not yet been explored.

Here we present the results of a study of changes in foraminiferal test size expressed by normalized volume deviation over the last 14000 years recorded in two sediment cores from the south-west Svalbard shelf and Storfjordrenna (Fig. 1). We relate test size changes to environmental conditions recorded at these sites by other proxies as well as to regional oceanic and climatic patterns described in the literature. The aim of the study is to examine the relationships between foraminiferal test sizes and environmental conditions and to

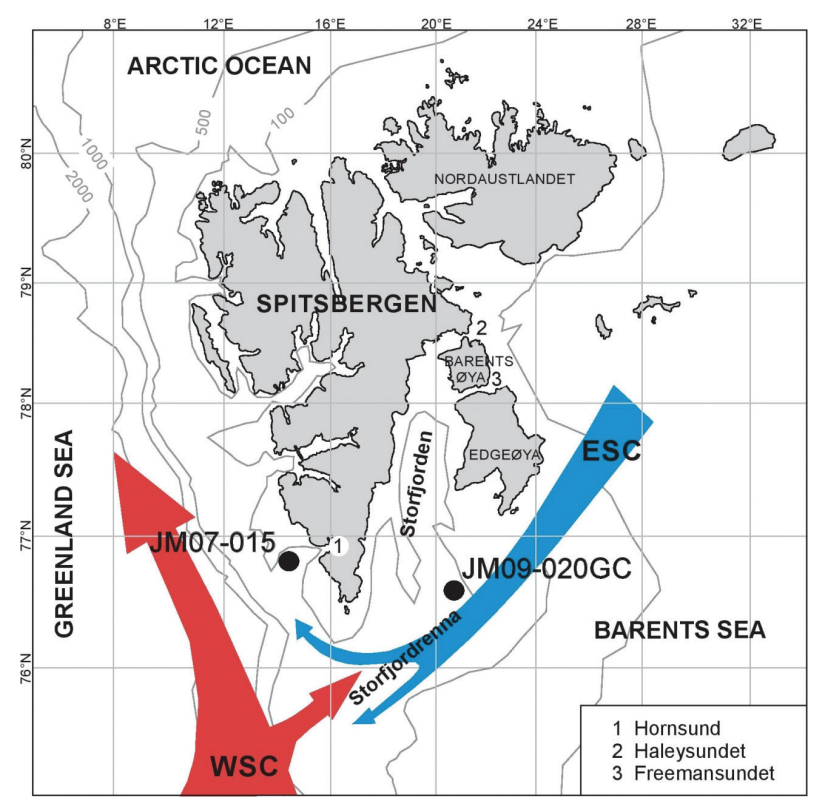

Fig. 1 Location map showing the present-day surface water circulation around the southern part of the main group of islands in the Svalbard Archipelago. The extraction locations of cores JM07-015 and JM09-020 are marked by black dots. Ocean currents are marked with arrows. determine whether benthic foraminiferal test size may be used as a proxy for environmental conditions over a millennial timescale.

\section{Oceanographic setting}

The bathymetry of the southern Svalbard shelf (which herein refers to the shelf off the southern part of the main group of islands in the Svalbard Archipelago, i.e., excluding the outlying island of Bjørnøya far to the south) was shaped mainly by glacial abrasion, which formed numerous banks dissected by deep, U-shaped depressions that represent former glacial valleys (Fig. 1). The area was finally deglaciated prior to 13 cal. Ky BP (Rüther et al. 2012). The present-day physical sedimentary environment on the southern Svalbard shelf is characterized by intensive winnowing, which led to the removal of fine-grained sediments on shelf bathymetric heights, the shelf break and the upper slope (Andruleit et al. 1996). Modern sediments are composed mainly of sandy-silty muds with coarse-grained deposits on top (Winkelmann \& Knies 2005). The delivery of terrigenous material to the shelf is minor because of the trapping of sediment in fjords. Ice-rafted debris is delivered mainly by sea ice from the Barents Sea (Vinje 2001) and by icebergs from tidewater glaciers (Błaszczyk et al. 2009).

The oceanographic regime of the southern Svalbard shelf is shaped by two coastal currents: the WSC, which transports AW $\left(S>34.9, T>3{ }^{\circ} \mathrm{C}\right.$; Saloranta 2001) northwards along the west Svalbard coast and the ESC, carrying a cold and less saline mixture of $\operatorname{ArW}\left(T<0^{\circ} \mathrm{C}, 34.4 \leq S \leq\right.$ 34.9) and Polar Water $(S<34.4)$. The WSC is considered to be the major pathway for both heat and saline water into the Arctic Ocean (Aagaard et al. 1985). The bottom topography of the southern Svalbard shelf prevents AW from reaching the coastline, while the flow of the ESC in the area is restricted to the continental shelf. On account of the vicinity of Hornsund, the coring site JM07-015 is also influenced by local waters, composed of glacial meltwater (Węsławski et al. 1995) and winter-cooled waters that form during the winter convective mixing and brine rejection (Zajączkowski et al. 2010). The mixing of AW, ArW and local waters results in the formation of TAW, which expands across the shelf and penetrates into the fjords (Cottier et al. 2005).

Storfjorden is an approximately $190-\mathrm{km}$ long glacial trough that is enclosed by the landmasses of Spitsbergen to the west and Edgeøya and Barentsøya to the east and is limited by the shallow Storfjordbanken in the south-east. The sound is connected with the north-western Barents Sea via Heleysundet to the north and via Freemansundet to the north-east. Storfjorden consists of two basins about 
$190 \mathrm{~m}$ deep, bordered by shallow (ca. $40 \mathrm{~m}$ ) shelves. A 120-m deep sill crosses the mouth of Storfjorden and separates the main basin from Storfjordrenna, a continuation of a trough that extends beyond the shelf break. The bottom depth along the axis of Storfjordrenna varies between 150 and $420 \mathrm{~m}$ (Pedrosa et al. 2011).

The water column in Storfjorden is composed of a mixture of two exogenous water masses and mixed waters that are formed locally. AW, carried by the WSC, enters Storfjorden in a cyclonic manner following the topography of the Barents Sea shelf break (Fer et al. 2003). ArW is transported by ESC and enters the trough via Freemansundet and Heleysundet as well as with a coastal current flowing into Storfjorden along Edgeøya. The Polar Front marks the boundary between the AW and ArW masses. In Storfjorden it is located along the slope of Storfjordrenna (Loeng 1991). TAW propagates along the Polar Front (Schauer 1995).

\section{Material and methods}

The study is based on material from two sediment cores. Core JM07-015 comes from a depression on the outer continental shelf off south-west Spitsbergen at a $148-\mathrm{m}$ water depth (Sternal et al. 2014; Fig. 1). Core JM09-020 was retrieved from Storfjordrenna, off southern Spitsbergen, at 253-m water depth (Eącka et al. 2015; Fig. 1). Age models of both cores are based on AMS ${ }^{14} \mathrm{C}$ dating (Sternal et al. 2014; Łącka et al. 2015). Additionally, in core JM07-015, modern sediment accumulation rates and an assessment of the core top recovery were based on the activity profiles of ${ }^{210} \mathrm{~Pb}$ and ${ }^{137} \mathrm{Cs}$ (Sternal et al. 2014). Study sites were proven to reflect general climatic fluctuations observed in the Svalbard area (Eącka et al. 2015; Telesiński et al. 2018).

Based on previous studies, five benthic species most abundant in both records were chosen for test measurements: Cibicides lobatulus, Cassidulina reniforme, Elphidium clavatum, Islandiella norcrossi and Nonionellina labradorica. Size fraction $>100 \mu \mathrm{m}$ was used in all foraminiferal analyses. Only samples containing at least 30 specimens of at least one of the species were selected for the study. Thirty-one samples were analysed in core JM07-015 and 45 in core JM09-020. Measurements were performed using a Nikon SMZ1 8 stereomicroscope equipped with a Nikon P2-SHR Plan Apo $1 \times$ lens and a Zeiss Axiocam 105 colour camera. In each analysed sample, 30 specimens of each of the above-mentioned species were measured. If a sample contained less than 30 specimens of a species, this species was omitted from the analysis in this sample. Two dimensions of each specimen were measured: the greatest diameter (i.e., the longest dimension of a shell) and the width (perpendicular to the greatest diameter). The size of the test was expressed as volume and was approximated by half of the volume of a sphere:

$$
V=\frac{1}{2} \times \frac{4}{3} \pi r^{3},
$$

where $r$ equals half of the mean of $\mathrm{W}$ and $\mathrm{L}$ (Hannah et al. 1994).

The only exception was $N$. labradorica, which was approximated by a truncated cone:

$$
V=\left[\frac{1}{3}\right] \pi h\left(r_{1}^{2}+r_{1} r_{2}+r_{2}^{2}\right),
$$

where $h$ equals $W, r_{1}$ (the radius of the base) equals half of the mean of $W$ and $L$ and $r_{2}$ (radius of the top) equals $0.4 r_{1}$ (modified after Hannah et al. 1994; Fig. 2). Arithmetic means of the volumes of the 30 specimens of each species in every analysed sample were calculated. Subsequently, these means were normalized to allow comparison of size changes between different species:

$$
V_{\text {norm. }}=\frac{v-v_{\text {mean }}}{\sigma},
$$

where $V$ is an arithmetic mean of a species test volume in a sample, $V_{\text {mean }}$ equals to an arithmetic mean of a species' test volume in the entire core and $\sigma$ is the standard deviation of a species' test volume in a core. The final output $V_{\text {norm }}$ is referred to as test normalized volume deviation. We decided to normalize the values of test sizes because of the large differences between species. The raw measurement data can be found in the Supplementary Data Set.

Finally, averages of normalized volume deviations of all species were calculated for each layer. In layers where (a)

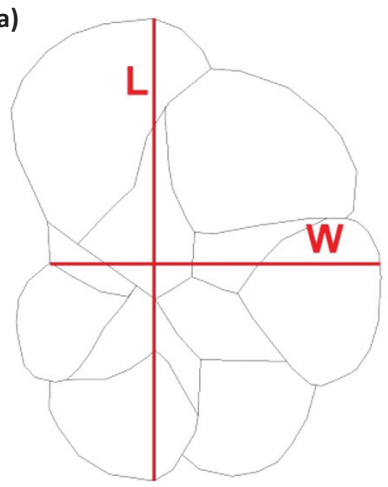

(b)

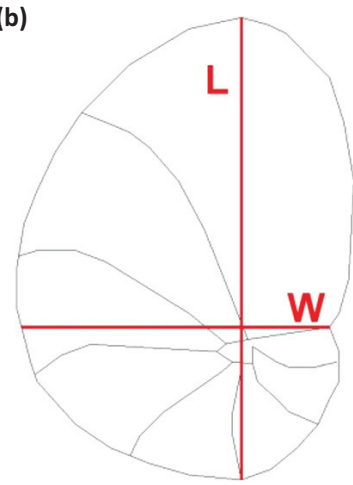

Fig. 2 Schematic drawing of measured dimensions in tests of (a) C. lobatulus, C. reniforme, E. clavatum, I. norcrossi and (b) N. labradorica. 
not all species were present, the mean was calculated using available normalized volumes of species.

Using statistical correlation, we analysed the normalized volume deviation of foraminiferal tests (the average of the five species) for a potential correlation between changes in test size and variations in different palaeoenvironmental proxies. The latter included: benthic $\delta^{18} \mathrm{O}$ (corrected for the ice volume effect [Fairbanks 1989]) and $\delta^{13} \mathrm{C}$, benthic foraminiferal flux and abundance and relative abundances of selected foraminiferal taxa grouped based on their ecological tolerances (AW indicators Buccella frigida and N. labradorica; ArW indicators I. norcrossi; glaciomarine fauna E. clavatum and C. reniforme; bottom current indicators Astrononion gallowayi and Cibicidoides lobatulus [Majewski et al. 2009; Telesiński et al. 2018]). The Pearson correlation coefficient $r$ was calculated and the statistical significance was determined (the significance threshold was set to $p<0.05$ ).

\section{Results}

Statistical regression analysis of the normalized volume deviations between pairs of species reveals that only some species correlate in test size changes. A significant correlation $(p<0.05)$ was found in five out of 10 analysed pairs of species in core JM09-020 and four out of 10 in core JM07-015 (Table 1). The normalized volume deviation of species C. reniforme correlates with most of the other species in both cores, while the species $N$. labradorica displays correlation with only one species. This shows a weakly positive relationship between test size of selected species.

The average normalized volume deviation records in both cores exhibit a consistent pattern and can be divided into three distinct intervals (Fig. 3). In the oldest part of the records (14-11.7 cal. Ky BP) the foraminiferal test volumes are relatively high in core JM07-015 (an average value of $0.51 \sigma$ ), while they oscillate slightly below the mean in core JM09-020 $(-0.27 \sigma)$. None of the samples from both cores contained a sufficient number of all the analysed species in this interval (e.g., I. norcrossi was completely absent). The averaged records are therefore distinctly variable as in some cases the mean was calculated from a single species (Supplementary Data Set). The results in this interval should be interpreted with particular caution as the observed changes in foraminiferal test size might be methodological artefacts rather than reflecting environmental evolution.

In the interval between 11.7 and ca. 8.5 cal. Ky BP the foraminiferal tests in both cores were generally small, with almost all volumes below the records' mean, in the case of individual species and the average was noted to be $-0.46 \sigma$ in JM07-015 and $-0.89 \sigma$ in JM09-020). In core JM07-015 all species, except for I. norcrossi, were present throughout the interval ( $N$. labradorica was absent in two and C. lobatulus in one out of 15 samples), while in core JM09-020 each species was missing in at least two out of 10 samples, while C. lobatulus was completely absent (Supplementary Data Set).

In the interval after $8.5 \mathrm{cal}$. Ky BP the foraminiferal test sizes are generally above the average in both records $(0.39 \sigma$ in JM07-015 and 0.31 $\sigma$ in JM09-020). Only at the end of the records (after ca. 1 cal. Ky BP in core JM07015 and after ca. 2 cal. Ky BP in core JM09-020) the tests tend to be smaller. In this interval, all of the measured species were present in all analysed samples (except for C. lobatulus, which was missing in three samples of core JM09-020; Supplementary Data Set) so the averaged records capture the variability of the entire fauna.

The statistical analysis of the foraminiferal test normalized volume deviation in both records shows a generally poor correlation with palaeoenvironmental proxies (Fig. 4). A significant correlation $(p<0.05)$ was found only in four out of 16 analysed cases. In core JM07-015, the normalized volume deviation correlates with the relative abundance of AW and ArW indicators (the Pearson correlation coefficient, $r$, equal to -0.52 and 0.36 , respectively). In core JM09-020 a statistically significant correlation of the normalized volume deviation was found only with the benthic $\delta^{18} \mathrm{O}$ record and benthic foraminiferal abundance ( $r$ equal to 0.47 and 0.36 , respectively).

Table 1 Significance values for regression analysis between pairs of species ( $p<0.05$ for significant correlation, in boldface) in cores JM09-020 and JM07-015.

\begin{tabular}{|c|c|c|c|c|c|}
\hline$p$-value & Elphidium clavatum & Cassidulina reniforme & Islandiella norcrossi & Cibicidoides lobatulus & Noninellina labradorica \\
\hline E. clavatum & - & $0.597^{b}$ & $0.006^{b}$ & $0.207^{b}$ & $<0.001^{b}$ \\
\hline C. reniforme & $<0.001^{a}$ & - & $0.009^{b}$ & $0.014^{b}$ & $0.058^{b}$ \\
\hline I. norcrossi & $0.022^{\mathrm{a}}$ & $0.087^{a}$ & - & $0.655^{b}$ & $0.002^{b}$ \\
\hline c. lobatulus & $<0.001^{a}$ & $0.009^{a}$ & $0.144^{a}$ & - & $0.821^{b}$ \\
\hline N. labradorica & $0.093^{a}$ & $0.468^{a}$ & $0.333^{a}$ & $0.445^{a}$ & - \\
\hline
\end{tabular}

aJM07-015. ' 'JM07-015. 


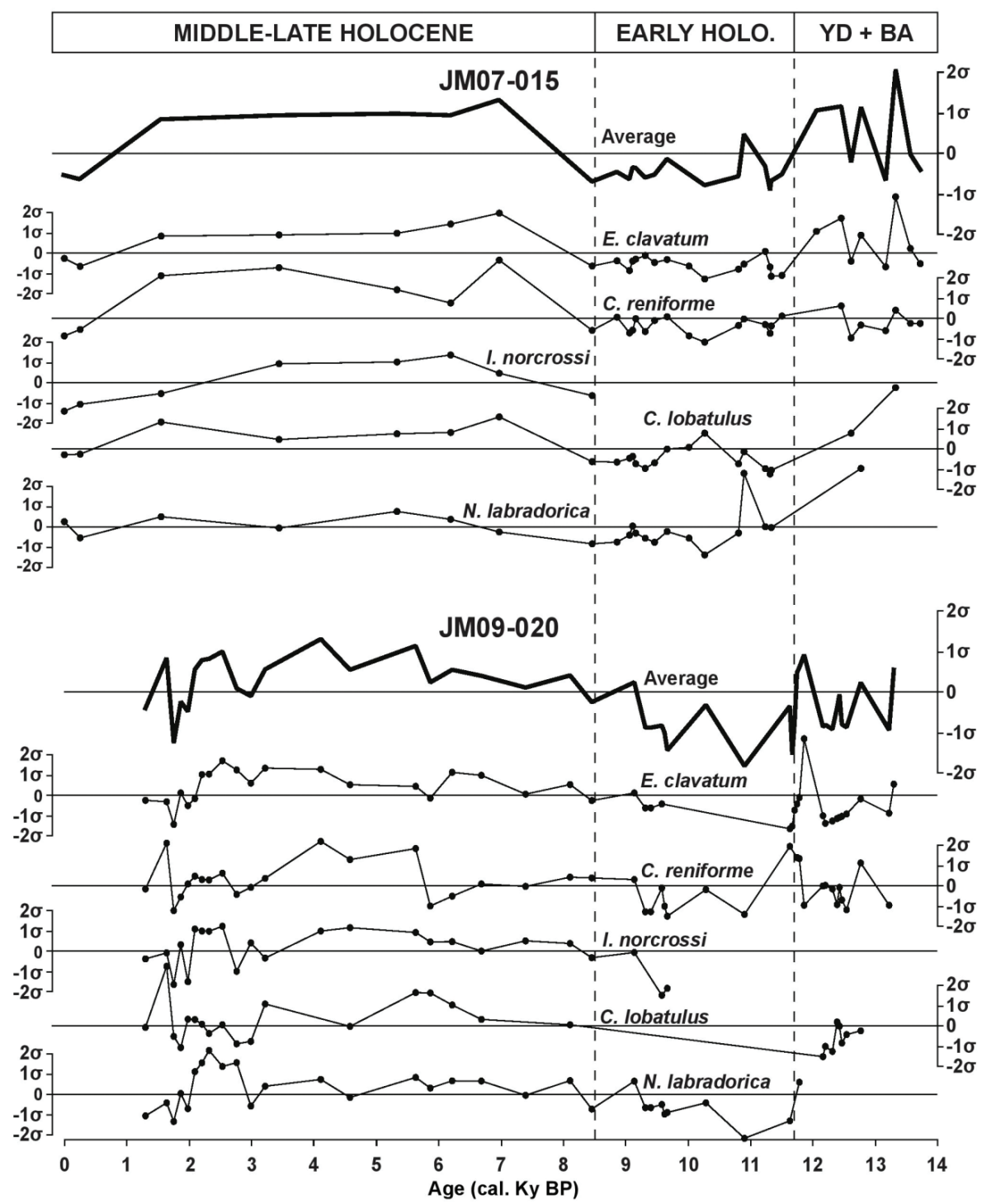

Fig. 3 Benthic foraminifera test normalized volume deviation of the five most common species and an average record for all the species versus age from cores JM07-015 and JM09-020.

Thus, none of the analysed palaeoenvironmental proxies shows a statistically significant correlation with the normalized volume deviation record of both cores.

\section{Discussion}

\section{Foraminiferal test size as a potential palaeoenvironmental proxy}

As demonstrated above, the foraminiferal test size records of the two analysed marine sediment cores show statistically significant correlations to different sets of palaeoenvironmental proxies and none of the proxies is mutual for both records (Fig. 4). Thus, the foraminiferal test size itself cannot be used as a palaeoenvironmental proxy in a straightforward manner. However, the foraminiferal test size in each of the cores correlates with some of the palaeoenvironmental proxies, indicating that the foraminiferal size depends on the oceanographic conditions of the coring sites. Additionally, the major foraminiferal test size changes (Fig. 3) coincide with global oceanographic transitions (i.e., YD/Holocene and early/mid-late Holocene boundaries).

The fact that the foraminiferal test size correlates with different palaeoenvironmental proxies at each of the study sites could be explained by differences in oceanographic properties of the settings. Site JM07015 is located on the open continental shelf, close to 

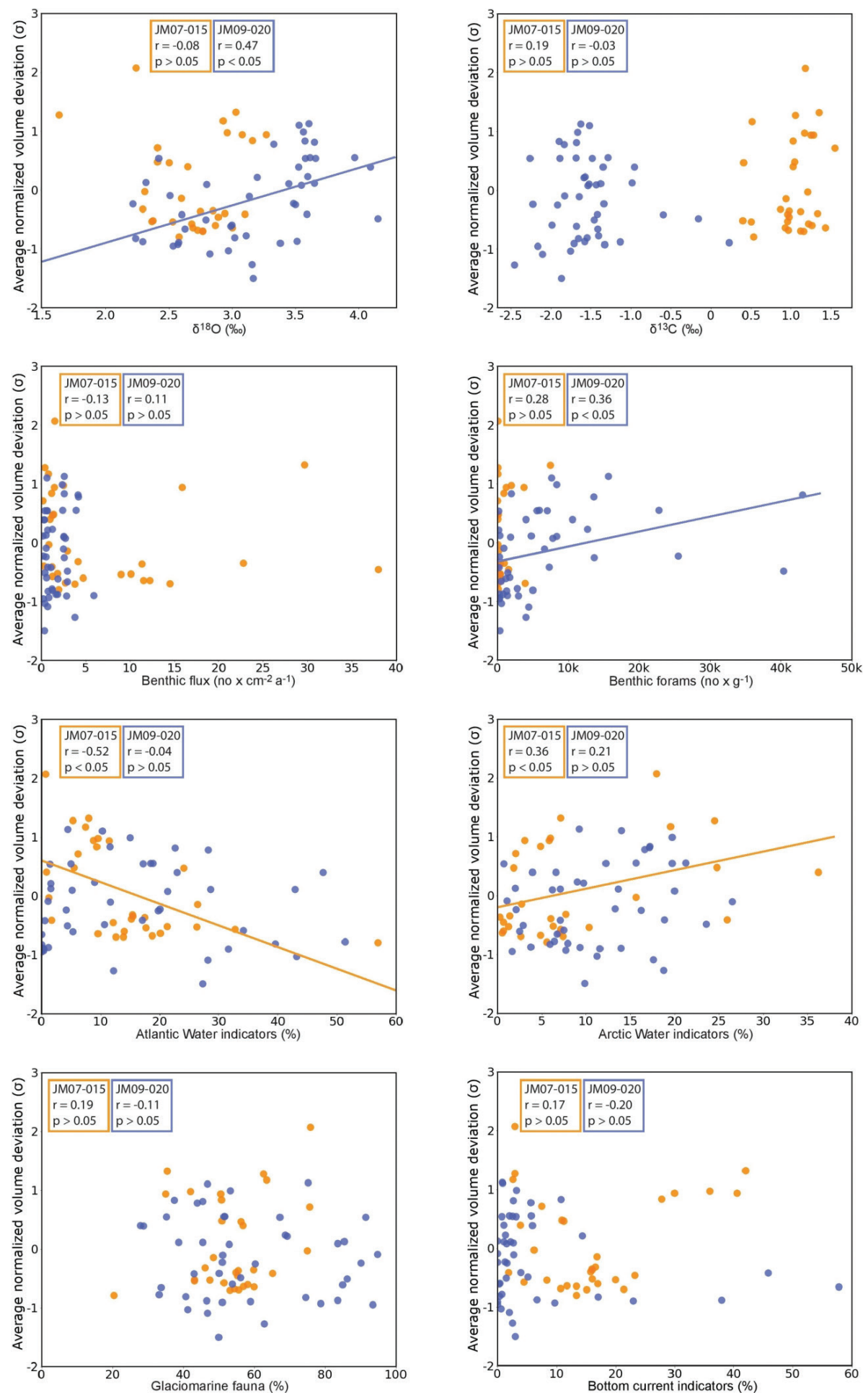

Fig. 4 Statistical correlation of the benthic foraminiferal test normalized volume deviation (an average of the five most common species) with other palaeoenvironmental proxies: benthic $\delta^{18} \mathrm{O}$ (corrected for the ice volume effect) and $\delta^{13} \mathrm{C}$, benthic foraminiferal flux and abundance and relative abundances of selected foraminiferal taxa grouped based on their ecological tolerances (AW indicators, ArW indicators, glaciomarine fauna and bottom current indicators [Majewski et al. 2009; Telesiński et al. 2018]). The Pearson correlation coefficients, $r$ and the $p$ values are shown for each correlation. Where there is significant correlation $(p<0.05)$, the regression line is shown. 
the main path of the WSC and the ESC, so the environmental conditions there depend to a large extent on the interplay between AW and ArW (Telesiński et al. 2018). In the JM07-015 core, foraminiferal test size was positively correlated with ArW indicators and negatively correlated with AW-indicating species (Fig. 4). Such dependency may suggest a connection between test size and ambient water temperatures, which is in line with findings that in relatively stable oxygen concentrations temperature plays an important role in determining foraminifera size (Keating-Bitonti \& Payne 2016). It is likely that at this site, the foraminifera reached larger test sizes in colder, less saline water to withstand less favourable conditions. In contrast, in AW dominated conditions they were able to reach reproductive maturity at an earlier stage and therefore stopped growing at smaller sizes (Boltovskoy \& Wright 1976).

The ocean environment at site JM09-020 is much more influenced by ArW, with sea ice playing an important role (Łącka et al. 2015). We therefore suggest that the abundance of sea ice and the position of the ice edge were the main factors influencing the foraminiferal fauna at this location. Sea ice transported by the ESC is produced mainly on vast Eurasian shelves, from relatively fresh and isotopically light water influenced by large Siberian rivers (e.g., Pfirman et al. 1997). Therefore, its melting might influence the surface salinity and stratification as well as the stable oxygen ratio of the ambient water. Furthermore, high surface-water productivity close to the sea-ice edge (e.g., Müller et al. 2011) provides high organic flux to the bottom-dwelling organisms and can promote the abundance of benthic foraminifera as well as their growth rates, while cold, isolated conditions under heavy sea-ice cover limit the development of benthic fauna. At this site, the small test size, as well as low abundance, were related to unfavourable living conditions under the heavy sea ice. The opposite indications were related to the high surface-water productivity zone close to the sea-ice edge.

No correlation between $\delta^{13} \mathrm{C}$ and the average foraminifera size was found at any of the study sites. This may imply a secondary role of the quality and quantity of organic matter on test morphology. Moreover, there is a large difference in stable carbon isotope ratios between coring sites that can be explained by the geographical location (Fig. 4). The isotopically light carbon signature at station JM09-020 is an effect of continental runoff supplying the Barents Sea in ${ }^{12} \mathrm{C}$ enriched waters from Siberia (Łącka et al. 2015). The heavier isotopic signature of station JM07-015 is in turn mainly shaped by the inflow of $\mathrm{AW}$, depleted in ${ }^{12} \mathrm{C}$ (Telesiński et al. 2018).

\section{Palaeoceanographic interpretation}

The oldest part of both records (14-1 1.7 cal Ky BP) covers the late BA interstadial and the YD cold period-intervals of rapid, high-amplitude environmental changes (e.g., McManus et al. 2004). The coring sites were under the influence of retreating Svalbard Barents Sea Ice Sheet (Sternal et al. 2014; Łącka et al. 2015; Telesiński et al. 2018). The release of large amounts of turbid meltwater from the retreating Svalbard Barents Sea Ice Sheet and heavy sea-ice cover limited the primary productivity (Knies et al. 1999) and the foraminiferal fauna periodically faced low food supply accompanied by other environmental disturbances such as, for example, low salinity or high sedimentation rates (Sternal et al. 2014; Łącka et al. 2015; Telesiński et al. 2018). However, the foraminiferal size response differed between the study sites. It is likely that in core JM07-015 foraminifera grew larger and reached reproductive maturity later in order to withstand unfavourable environmental conditions (Bradshaw 1961; Boltovskoy \& Wright 1976). On the other hand, the growth and reproduction of benthic foraminifera at site JM09-020 have been highly restricted by unfavourable environmental conditions (Boltovskoy \& Wright 1976; Nigam et al. 2006). However, many species used for this study were absent in this interval (Supplementary Data Set) and the results should be treated with care.

The early Holocene interval (ca. 8.5-11.7 cal. Ky BP) was characterized by the smallest foraminiferal tests in both records (Fig. 3). On the south-west Svalbard shelf, the strong AW inflow created favourable environmental conditions in which benthic foraminifera reached reproductive maturity earlier, resulting in small foraminiferal test sizes (Bradshaw 1961; Boltovskoy \& Wright 1976). Numerous palaeoenvironmental reconstructions have indicated increased heat flux from the stronger AW inflow to the south-west Svalbard shelf as a cause for the early Holocene warming, along with high solar insolation (Rasmussen et al. 2007; Ślubowska-Woldengen et al. 2007; Sternal et al. 2014; Telesiński et al. 2018). Nevertheless, until 9.2 cal. Ky BP Storfjordrenna still belonged to the ArW domain (Eącka et al. 2015). Intensive deglaciation was associated with large amounts of meltwater released from the retreating ice front, decreased surface salinity and increased water column stratification, limiting food supply and ventilation of the bottom waters. Such environmental conditions reduced benthic foraminiferal abundance as well as their growth, as seen in our record (Fig. 5). However, it is worth noting that the distinctly small size of foraminifera in both cores during the Early Holocene can be also explained by ambient water temperatures, as the region of Svalbard in the early 


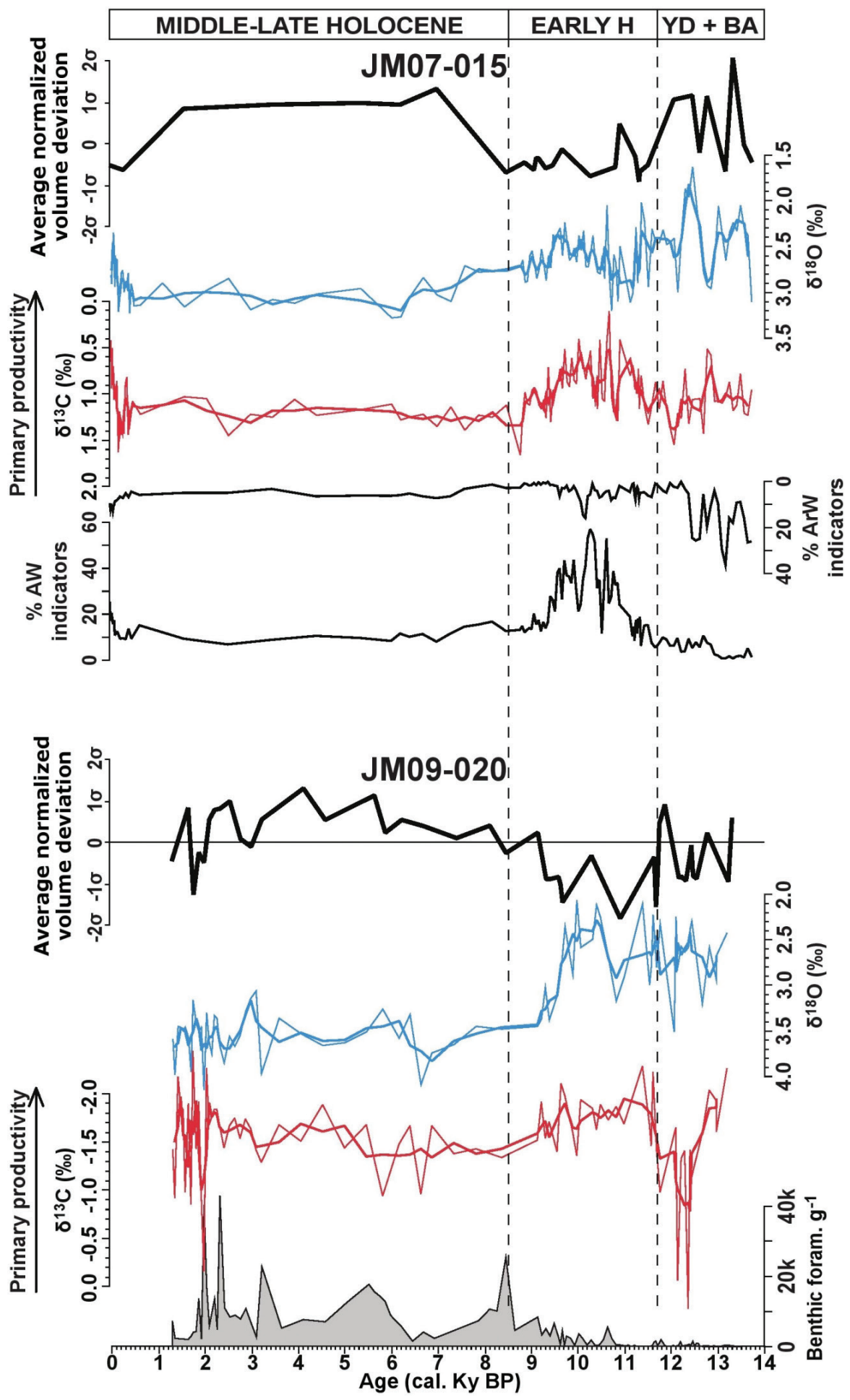

Fig. 5 Palaeoceanographic data of cores (a) JM07-015 and (b) JM09-020 versus age. Average benthic foraminiferal test size (thick black lines, expressed as a standard deviation from the average in the core), benthic stable oxygen isotope record (thin blue lines are raw data; thick blue lines represent three-point running means), benthic stable carbon isotope record (thin red lines indicate raw data; thick red lines are three-point running means). In (a) the relative abundance of ArW- and AW-indicating species is indicated with thin black lines. In (b) benthic foraminiferal abundance is indicated in grey as specimens per $1 \mathrm{~g}$ dry sediment. Stable isotope and faunal data for core JM07-015 are from Telesiński et al. (2018) and for core JM09-020 from tącka et al. (2015). 
Holocene was outstandingly warm in the palaeoceanographic record (Sarnthein et al. 2003; Hald et al. 2004).

The middle to late Holocene interval (after ca. 8.5 cal. Ky BP) was characterized by a relatively large foraminiferal test size in both records (Fig. 5). Storfjordrenna remained under the influence of AW throughout the middle to late Holocene and a significant reduction in the amount of freshwater and ArW was observed (Eącka et al. 2015). Therefore, the large tests are in agreement with heavy $\delta^{18} \mathrm{O}$ values related to AW dominance. In contrast, on the south-west Svalbard shelf, the AW inflow over the middle to late Holocene compared to the early Holocene. Although Telesiński et al. (2018) indicated, on the basis of the benthic foraminiferal flux and $\delta^{18} \mathrm{O}$ record, that the maximum AW advection lasted until 6.1 cal. Ky $\mathrm{BP}$, the AW-indicating species started to decline already around 9 cal. Ky BP, slightly preceding the foraminiferal test size increase in our record. Thus, the large foraminiferal tests on the south-west Svalbard shelf after ca. 8.5 cal. Ky BP may be interpreted as indicating decreasing AW inflow. Interestingly, this suggests that the increase in foraminiferal test size correlates with an opposite change in AW inflow at two different sites (i.e., test size increases when the AW inflow increases in the Strofjordrenna and decreases on the south-west Svalbard shelf). This ambiguity confirms the fact that foraminiferal test size cannot be used as a straightforward, independent proxy as it relies on an interplay of local environmental conditions.

At both our sites the foraminiferal test size tends to decrease in the latest Holocene (Fig. 5). According to our statistical analysis (Fig. 4), a distinct decrease observed in the south-west Svalbard shelf within the last millennium is associated with an increase in AW inflow and a decrease in ArW inflow. This is, however, in contradiction with other proxies (Telesiński et al. 2018) indicating an increase in ArW inflow, ice-rafted debris supply and a return of more glaciomarine fauna related with the Little Ice Age. This apparent discrepancy is difficult to explain with available data and might suggest different factors influencing the foraminiferal test size though it might as well be an artefact of low sampling resolution. On the other hand, it indicates increased variability in the latest Holocene which is in agreement with numerous other studies (e.g., Spielhagen et al. 2011 ; Werner et al. 201 1; Telesiński et al. 2015). A significant decrease in the foraminiferal test size observed around $2 \mathrm{cal}$. Ky BP in Storfjordrenna was simultaneous with light $\delta^{18} \mathrm{O}$ excursions that might suggest that they were related with either perturbation in the AW advection or ArW outflow and the strong sea-ice fluctuations in the Fram Strait (Müller et al. 2012). Similar to the JM07-015 record, these changes indicate increased variability in the latest Holocene. As demonstrated by, for example, Müller et al. (2012) and Telesiński et al. (2014), when gradual changes in insolation and the related cooling reach a certain threshold, they can result in a stepwise change or increased variability of other environmental parameters such as sea-ice cover, ocean circulation, sediment supply and faunal distribution.

\section{Summary and conclusion}

A case study of two sediment records from the southern Svalbard shelf covering the late deglaciation and the Holocene shows statistically significant, site-specific relationships between benthic foraminiferal test size variability and other palaeoenvironmental parameters. On the south-west Svalbard shelf (site JM07-015) the foraminifera reached larger test sizes in colder, less saline water, most probably to be able to withstand less favourable conditions. In contrast, in AW-dominated conditions they were able to reach reproductive maturity at an earlier stage and therefore grew to smaller sizes. In Storfjordrenna (site JM09-020), strongly influenced by the cold, low-salinity ESC, the small foraminiferal test size, as well as low abundance, might be related to unfavourable living conditions under the heavy sea ice.

This study suggests that there is no clear and universal dependency between the foraminiferal test size and other analysed proxies. The lack of a straightforward relationship shows that the foraminiferal test volume cannot be used as an independent proxy without referring to other palaeoenvironmental parameters. Even though the general pattern of the foraminiferal test size changes over the last 14000 years looks similar in the two analysed records, the influence of major oceanographic transitions probably has a secondary impact. The fact that the foraminifera size correlates with different proxies at different sites suggests that local conditions have a foremost role in shaping foraminifera morphology.

\section{Acknowledgements}

The authors thank Agnieszka Kujawa and Magdalena Łącka for performing the foraminiferal test size measurements. The authors also thank Sergei Korsun and an anonymous reviewer for their constructive feedback and insightful comments that helped improve this manuscript.

\section{Disclosure statement}

The authors report no conflict of interest. 


\section{Funding}

The study was funded by the Polish-Norwegian Research Programme operated by the National Centre for Research and Development, Poland, under the Norwegian Financial Mechanism 2009-2014 in the frame of Project Contract no. Pol-Nor/201992/93/2014. MMT, NS and JP were supported by grant nos. 2016/21/D/ST10/00785, 2016/23/N/ ST10/01382 and 2015/19/D/ST10/00244, respectively, funded by the National Science Centre, Poland. Language editing was supported by grant no. 2018/31/B/ST10/01616, funded by the National Science Centre, Poland.

\section{References}

Aagaard K., Swift J.H. \& Carmack E.C. 1985. Thermohaline circulation in the Arctic Mediterranean seas. Journal of Geophysical Research-Oceans 90, 4833-4846, doi: 10.1029/ JC090iC03p04833.

Andruleit H., Freiwald A. \& Schäfer P. 1996. Bioclastic carbonate sediments on the southwestern Svalbard shelf. Marine Geology 134, 163-182, doi: 10.1016/0025-3227(96) 00044-8.

Bandy O.L. 1963. Larger living foraminifera of the continental borderland of southern California. Contributions from the Cushman Foundation for Foraminiferal Research 14, 121-126.

Bernhard J.M. 1986. Characteristic assemblages and morphologies of benthic foraminifera from anoxic, organic-rich deposits: Jurassic through Holocene. Journal of Foraminiferal Research 16, 207-215, doi: 10.2113/gsjfr.16.3.207.

Błaszczyk M., Jania J.A. \& Hagen J.O. 2009. Tidewater glaciers of Svalbard: recent changes and estimates of calving fluxes. Polish Polar Research 30, 85-142.

Boltovskoy E. \& Wright R. 1976. Recent foraminifera. The Hague: Junk.

Bradshaw J.S. 1955. Preliminary laboratory experiments on ecology of foraminiferal populations. Micropaleontology 1, 351-358.

Bradshaw J.S. 1961. Laboratory experiments on the ecology of foraminifera. Contributions from the Cushman Foundation for Foraminiferal Research 12, 87-106.

Corliss B. \& Silva K.A. 1993. Rapid growth of deepsea benthic foraminifera. Geology 21, 991-994, doi: 10.1130/0091-7613(1993)021<0991:RGODSB>2.3.CO;2.

Cottier F., Tverberg V., Inall M., Svendsen H., Nilsen F. \& Griffiths C. 2005. Water mass modification in an Arctic fjord through cross-shelf exchange: the seasonal hydrography of Kongsfjorden, Svalbard. Journal of Geophysical ResearchOceans 110, 1-18, doi: 10.1029/2004JC002757.

Duchemin G., Fontanier C., Jorissen F.J., Barras C. \& Griveaud C. 2007. Living small-sized $(63-150 \mu \mathrm{m})$ foraminifera from mid-shelf to mid-slope environments in the Bay of Biscay. Journal of Foraminiferal Research 37, 12-32, doi: 10.2113/gsjfr.37.1.12.

Fairbanks R.G. 1989. A 17,000-year glacio-eustatic sea level record: influence of glacial melting rates on the Younger
Dryas event and deep-ocean circulation. Nature 342, 637642, doi: 10.1038/342637a0.

Fer I., Skogseth R., Haugan P.M. \& Jaccard P. 2003. Observations of the Storfjorden overflow. Deep-Sea Research Part I 50, 1283-1303, doi: 10.1016/S0967-0637(03)00124-9.

Gross O. 2000. Influence of temperature, oxygen and food availability on the migrational activity of bathyal benthic foraminifera: evidence by microcosm experiments. Hydrobiologia 426, 123-137, doi: 10.1023/A:1003930831220.

Hald M., Ebbesen H., Forwick M., Godtliebsen F., Khomenko L., Korsun S., Ringstad Olsen L. \& Vorren T.O. 2004. Holocene paleoceanography and glacial history of the west Spitsbergen area, Euro-Arctic margin. Quaternary Science Reviews 23, 2075-2088, doi: 10.1016/j. quascirev.2004.08.006.

Hannah F., Rogerson A. \& Laybourn-Parry J. 1994. Respiration rates and biovolumes of common benthic foraminifera (Protozoa). Journal of the Marine Biological Association of the United Kingdom 74, 301-312, doi: 10.1017/ s0025315400039345.

Kaiho K. 1994. Benthic foraminiferal dissolved-oxygen index and dissolved-oxygen levels in the modern ocean. Geology22, 719-722, doi: 10.1130/0091-7613(1994)022<0719:BFDO IA>2.3.CO;2.

Kaiho K. 1998. Global climatic forcing of deep-sea benthic foraminiferal test size during the past 120 m.y. Geology 26, 491-494, doi: 10.1130/0091-7613(1998)026<0491:GCFO DS>2.3.CO;2.

Keating-Bitonti C.R. \& Payne J.L. 2016. Physicochemical controls on biogeographic variation of benthic foraminiferal test size and shape. Paleobiology 42, 595-611, doi: 10.1017/pab.2016.7.

Keating-Bitonti C.R. \& Payne J.L. 2018. Environmental influence on growth history in marine benthic foraminifera. Paleobiology 44, 736-757, doi: 10.1017/pab.2018.19.

Knies J., Vogt C. \& Stein R. 1999. Late Quaternary growth and decay of the Svalbard/Barents Sea ice sheet and paleoceanographic evolution in the adjacent Arctic Ocean. Geo-Marine Letters 18, 195-202, doi: 10.1007/s003670050068.

Kuroyanagi A., Kawahata H., Suzuki A., Fujita K. \& Irie T. 2009. Impacts of ocean acidification on large benthic foraminifers: results from laboratory experiments. Marine Micropaleontology 73, 190-195, doi: 10.1016/j.marmicro.2009.09.003.

Łącka M., Zajączkowski M., Forwick M. \& Szczuciński W. 2015. Late Weichselian and Holocene paleoceanography of Storfjordrenna, southern Svalbard. Climate of the Past 11, 587-603, doi: 10.5194/cpd-10-3053-2014.

Le Cadre V., Debenay J.-P. \& Lesourd M. 2003. Low pH effects on Ammonia beccarii test deformation: implications for using test deformations as a pollution indicator. Journal of Foraminiferal Research 33, 1-9, doi: 10.2113/0330001.

Lewis K.B. \& Jenkins C. 1969. Geographical variation of Nonionellina flemingi. Micropaleontology 15, 1-12.

Loeng H. 1991. Features of the physical oceanographic conditions of the Barents Sea. Polar Research 10, 5-18, doi: 10.1111/j.1751-8369.1991.tb00630.x.

Majewski W., Szczuciński W. \& Zajączkowski M. 2009. Interactions of Arctic and Atlantic water-masses and 
associated environmental changes during the last millennium, Hornsund (SW Svalbard). Boreas 38, 529-544, doi: $10.1111 / \mathrm{j} .1502-3885.2009 .00091 . x$.

McManus J.F., Francois R., Gherardi J.-M., Keigwin L.D. \& Brown-Leger S. 2004. Collapse and rapid resumption of Atlantic meridional circulation linked to deglacial climate changes. Nature 428,834-837, doi: 10.1038/ nature02494.

Müller J., Wagner A., Fahl K., Stein R., Prange M. \& Lohmann G. 2011. Towards quantitative sea ice reconstructions in the northern North Atlantic: a combined biomarker and numerical modelling approach. Earth and Planetary Science Letters 306, 137-148, doi: 10.1016/j.epsl.2011.04.011.

Müller J., Werner K., Stein R., Fahl K., Moros M. \& Jansen E. 2012. Holocene cooling culminates in sea ice oscillations in Fram Strait. Quaternary Science Reviews 47, 1-14, doi: 10.1016/j.quascirev.2012.04.024.

Murray J.W. 2006. Ecology and applications of benthic foraminifera. Cambridge: Cambridge University Press.

Nigam R., Kurtarkar S.R., Saraswat R. \& Linshy V.N. 2008. Response of benthic foraminifera Rosalina leei to different temperature and salinity, under laboratory culture experiment. Journal of the Marine Biological Association of the United Kingdom 88, 699-704, doi: 10.1017/S0025315408001197.

Nigam R., Saraswat R. \& Kurtarkar S.R. 2006. Laboratory experiment to study the effect of salinity variations on benthic foraminiferal species-Pararotalia nipponica (Asano). Journal of the Geological Society of India 67, 41-46.

Pedrosa M.T., Camerlenghi A., De Mol B., Urgeles R., Rebesco M., Lucchi R.G. \& shipboard participants of the SVAIS and EGLACOM cruises 2011. Seabed morphology and shallow sedimentary structure of the Storfjorden and Kveithola trough-mouth fans (north west Barents Sea). Marine Geology 286, 65-81, doi: 10.1016/j.margeo.2011.05.009.

Pfirman S.L., Colony R., Nürnberg D., Eicken H. \& Rigor I. 1997. Reconstructing the origin and trajectory of drifting Arctic sea ice. Journal of Geophysical Research-Oceans 102, 12575-12586, doi: 10.1029/96JC03980.

Rasmussen T.L. \& Thomsen E. 2015. Palaeoceanographic development in Storfjorden, Svalbard, during the deglaciation and Holocene: evidence from benthic foraminiferal records. Boreas 44, 24-44, doi: 10.1111/bor.12098.

Rasmussen T.L., Thomsen E., Ślubowska M.A., Jessen S.P., Solheim A. \& Koç N. 2007. Paleoceanographic evolution of the SW Svalbard margin $\left(76^{\circ} \mathrm{N}\right)$ since $20,000{ }^{14} \mathrm{C}$ yr BP. Quaternary Research 67, 100-114, doi: 10.1016/j. yqres.2006.07.002.

Rüther D.C., Bjarnadóttir L.R., Junttila J., Husum K., Rasmussen T.L., Lucchi R.G. \& Andreassen K. 2012. Pattern and timing of the northwestern Barents Sea Ice Sheet deglaciation and indications of episodic Holocene deposition. Boreas 41, 494-512, doi: 10.1111/j.1502-3885.2011.00244.x.

Saloranta T.M. 2001. Hydrographic structure of the sea west of Svalbard along and across the continental slope. Reports in Meteorology and Oceanography 2. Bergen: University of Bergen.

Sarnthein M., van Kreveld S., Erlenkeuser H., Grootes P.M., Kucera M., Pflaumann U. \& Schulz M. 2003. Centennial-to-millennial-scale periodicities of Holocene climate and sediment injections off the western Barents shelf, $75^{\circ} \mathrm{N}$. Boreas 32, 447-461, doi: 10.1080/03009480310003351.

Schauer U. 1995. The release of brine-enriched shelf water from Storfjord into Norwegian Sea. Journal of Geophysical Research-Oceans 100, 16015-16028, doi: 10.1029/95JC01184.

Ślubowska-Woldengen M., Koç N., Rasmussen T.L., Klitgaard-Kristensen D., Hald M. \& Jennings A.E. 2008. Timeslice reconstructions of ocean circulation changes on the continental shelf in the Nordic and Barents seas during the last 16,000 cal yr B.P. Quaternary Science Reviews 27, 14761492, doi: 10.1016/j.quascirev.2008.04.015.

Ślubowska-Woldengen M., Rasmussen T.L., Koç N., Klitgaard-Kristensen D., Nilsen F. \& Solheim A. 2007. Advection of Atlantic Water to the western and northern Svalbard shelf since 17,500 cal yr BP. Quaternary Science Reviews 26, 463-478, doi: 10.1016/j.quascirev.2006. 09.009.

Spielhagen R.F., Werner K., Aagaard-Sørensen S., Zamelczyk K., Kandiano E.S., Budéus G., Husum K., Marchitto T.M. \& Hald M. 2011. Enhanced modern heat transfer to the Arctic by warm Atlantic Water. Science 331, 450-453, doi: 10.1126/science.1197397.

Sternal B., Szczuciński W., Forwick M., Zajączkowski M., Lorenc S. \& Przytarska J.E. 2014. Postglacial variability in near-bottom current speed on the continental shelf off south-west Spitsbergen. Journal of Quaternary Science 29, 767-777, doi: 10.1002/jqs.2748.

Stouff V., Geslin E., Deenay J.-P. \& Lesourd M. 1999. Origin of morphological abnormalities in Ammonia (Foraminifera): studies in laboratory and natural environments. Journal of Foraminiferal Research 29, 152-170, doi: 10.2113/ gsjfr.29.2.152.

Telesiński M.M., Bauch H.A., Spielhagen R.F. \& Kandiano E.S. 2015. Evolution of the central Nordic Seas over the last 20 thousand years. Quaternary Science Reviews 121, 98-109, doi: 10.1016/j.quascirev.2015.05.013.

Telesiński M.M., Przytarska J.E., Sternal B., Forwick M., Szczuciński W., Łącka M. \& Zajączkowski M. 2018. Palaeoceanographic evolution of the SW Svalbard shelf over the last 14000 years. Boreas 47, 410-422, doi: 10.1111 /bor. 12282.

Telesiński M.M., Spielhagen R.F. \& Lind E.M. 2014. A high-resolution Lateglacial and Holocene palaeoceanographic record from the Greenland Sea. Boreas 43, 273285, doi: 10.1111/bor.12045.

Theyer F. 1971. Size-depth variation in the foraminifer Cyclammina cancellata Brady from the Peru-Chile trench area. Antarctic Research Series 15, 309-313.

Vinje T. 2001. Anomalies and trends of sea-ice extent and atmospheric circulation in the Nordic seas during the period 1864-1998. Journal of Climate 14, 255-267, doi: 10.1175/1520-0442(2001)014<0255:AATOSI>2.0.CO;2.

Werner K., Spielhagen R.F., Bauch D., Hass H.C., Kandiano E.S. \& Zamelczyk K. 2011. Atlantic Water advection to the eastern Fram Strait-multiproxy evidence for late Holocene variability. Palaeogeography, Palaeoclimatology, Palaeoecology 308, 264-276, doi: 10.1016/j. palaeo.2011.05.030. 
Węsławski J.M., Koszteyn J., Zajączkowski M., Wiktor J. \& Kwaśniewski S. 1995. Freshwater in Svalbard fjord ecosystem. In H.R. Skjoldal et al. (eds.): Ecology of fjords and coastal waters. Pp. 229-214. Amsterdam: Elsevier.

Winkelmann D. \& Knies J. 2005. Recent distribution and accumulation of organic carbon on the continental margin west off Spitsbergen. Geochemistry, Geophysics, Geosystems 6, article no. Q09012, doi: 10.1029/2005GC000916.

Zajączkowski M., Szczuciński W., Plessen B. \& Jernas P. 2010. Benthic foraminifera in Hornsund, Svalbard: implications for paleoenvironmental reconstructions. Polish Polar Research 31, 349-375, doi: 10.2478/v10183. 